\title{
Representações Públicas
}

\author{
Antônio Chaves \\ Catedrático de Direito Civil da Faculdade \\ de Direito da Universidade de São Paulo
}

\begin{abstract}
SUMARIO: 1. Conceito - 2. o contrato de representasão Naturea Plartes intervenientes - 3. Obrigacões e direitos do empresário - 4. Obrigaszes e direitos do autor - 5. Recebimento e Impenhorabilidade - 6. Participacão de artistas remunerados $e$ intuito de lucro - 7. \$ubvenisões, lajudas de custo, etc., integram a renda bruta da pega teatral 8. A venda de "posters" e programas ilustrados (e que tramscrevem trechos da peça teatral) fazem parte, também, da renda bruta da peça 9. Duração do contrato. Suspensão e resolução - 10. A representacão, de lege ferenda.
\end{abstract}

\section{Conceito}

As empresas teatrais são de origem antiguíssima, tendo mesmo constituido o ponto de partida não só da lei pioneira francesa de 1871, para o surto de disposições legislativas relacionadas com o direito de autor, como também para a fundação da primeira entidade de defesa: a Sociedade dos Autores e Compositores Dramáticos, por SCRIBE, aos 07-03-1829.

Certamente, comédias e dramas podem ser representados independentemente da sua reprodução em caracteres tipográficos, tal como se verifica, com maior nitidez ainda, com a execução das peças musicais.

Quando, porém, ocorre semelhante multiplicação em exemplares, a aquisição de um deles não esgota sua finalidade pela leitura privada: permite também sua representação pública, que, tal como a execução em público de um disco ou de um cassete, não é lícita a não ser com o consentimento do autor.

$\mathrm{O}$ art. 27 da lei francesa, enumera como meios de comunicação direta da obra ao público:

- recitação pública;

- execução lírica;

- representação dramática; 
- apresentação pública;

- difusão por qualquer processo das palavras, dos sons ou das imagens;

- projeção pública;

- transmissão da obra radiodifundida pelo meio de um altofalante e eventualmente de uma tela de radiotelevisão colocada em lugar público.

São todos meios de comúnicação incorpórea, ou direta, por entrar a obra em contato com o público sem a intermediação de um exemplar ou suporte material que possa manusear.

Não definiram o que sejam representação e execução nem a lei $\mathrm{n}^{\circ} 5.988$ nem o Código Civil, que se limitava a dispor, no antiquado art. 657, entender-se anuir o autor, publicada e exposta à venda uma obra teatral ou musical, a que se represente, ou execute, onde quer que a sua audição não for retribuida.

Por representação, na acepção que nos interessa, entende-se pois a execução artística por meio de espetáculo público, ou, como quer VALERIO DE SANCTIS, "apresentar a obra ao público, numa sua realização interpretativa, auditiva ou audiovisual."

"De um modo geral" - elucida a Guide de la Convention de Berne, Genève, Ompi, 1978, pág. 74 —, "representação" aplica-se às obras dramáticas ou dramático-musicais porque etimologicamente significa a ação de desempenhar peças numa cena; assim tanto obras teatrais puramente dramáticas, como acompanhadas de música (ópera, operetas, comédias musicais, etc). Por outro lado, a palavra "execução" é antes empregada para as obras musicais, porque ela implica a idéia de interpretação da partitura.

A Convenção de Berna para a Proteção das Obras Literárias e Artísticas, revista em Paris a 24-07-1971, que, por ter sido promulgada entre nós pelo Dec. 75.699, de 06-05-1975, também é lei interna, com relação aos jurisdicionados dos países signatários, reconhece aos autores de obras dramáticas, dramático-musicais e musicais o direito exclusivo de autorizar:

$1^{9}$ - a representação e a execução públicas das suas obras, inclusive a representação e a execução pública por todos os meios e processos;

$2^{\circ}$ - a transmissão pública por todos os meios da representação e da execução das suas obras.

Os mesmos direitos são concedidos aos autores de obras dramáticas ou dramático-musicais, por toda a duração dos seus direitos sobre a obra original, no que respeita à tradução das suas obras (art. 11). 
Estabelece a lei francesa diferença entre a comunicação direta, que ocorre quando os destinatários são convocados a perceber a interpretação de uma obra, como no caso da obra dramática, - e a comunicação indireta, constituída através da reprodução de uma criação literária, musical, artística (edição gráfica), ou a gravação de uma interpretação (edição sonora).

Critica HENRI DESBOIS a terminologia da lei, considerando que teria sido melhor recorrer à idéia de comunicação do que ao direito chamado de representação, muito embora ao conceito de reprodução, que atinge o fato da cópia ou da gravação, contraponha-se ao direito de comunicação direta ou indireta:

"Se o Parlamento sacrificou a propriedade das expressões, é muito verossimilmente, porque a noção de representação beneficiava da autoridade de uma tradição muito longa, mas para remediar à estreiteza do conceito, concretizou longo seu pensamento dando numerosos exemplos daquele dos dois direitos que ela opunha ao direito de reprodução".

Basta percorrer o dispositivo do art. 27 da lei francesa - adita que apresenta uma lista não exaustiva de iniciativas submetidas ao direito de representação, para concluir que os redatores, com a expressão - representação - cobrem toda uma gama de prestações, diferentes por natureza de um espetáculo dramático.

Realça outrossim que o modo técnico de designação das iniciativas, que são tributárias do direito chamado de representação, é o que figura desde a primeira linha do mencionado dispositivo: "comunicação direta da obra ao público", em oposição à "fixação material da obra por todos os processos que permitem comunicá-la ao público de uma maneira indireta", isto é, a reprodução.

Põe em realce o defeito da terminologia, uma vez que muitas comunicações, qualificadas de diretas pelo vocabulário do art. 27 , tem lugar por intermédio de um suporte material, ao invés de ser o fato de intérpretes ou de atores que se apresentam diante do público, como é o caso da audição de discos e da projeção de filmes.

Conseqüentemente, comunicação direta e indireta teriam podido designar, com mais exatidão, respectivamente, a representação ou a interpretação propriamente dita, de uma parte, e a audição de um disco ou a projeção de um filme, de outra parte. E mesmo, no quadro da comunicação indireta tomaria lugar a emissão radiofônica ou televisual, que é tratada como uma representação propriamente dita: um agente de difusão se interpõe entre a execução e a percepção, uma vez que as ondas trasmitem as emissões através do espaço como os discos ou os filmes garantem a duração a impressões fugidias.

Recrimina ainda que o inventário não tenha sido levantado com mais atenção. A "representação dramática" correspondente aos espetá- 
culos de execução lírica e recitação pública, porque, diferentemente da audição de um disco ou da projeção de um filme, não implicam a intervenção de um suporte material, sobre o qual tenham sido fixados os sons ou as imagens. Tratar-se-ia, mais propriamente, de uma comunicação imediata, entre presentes, do intérprete aos espectadores ou aos ouvintes:

" $E$ em virtude de uma tradição firmemente estabelecida que as execuções líricas foram assimiladas às interpretações de obras teatrais, devendo-se por isso entender, não somente as óperas ou as óperas-cômicas, mas todas as obras de canto, acompanhadas ou não por instrumentos".

Subordina o art. 30 da lei $\mathrm{n}^{\circ} 5.988$ à permissão do autor de obra literária, artística ou científica, qualquer forma de sua utilização, exemplificando:

I. a edição;

II. a tradução para qualquer idioma;

III. a adaptação ou inclusão em fonograma ou película cinematográfica;

IV . a comunicação ao público, direta ou indireta, por qualquer forma ou processo.

Como tipificação desta última modalidade, limita-se a indicar:

a) execução, representação, recitação ou declamação;

b) radiodifusão sonora ou audiovisual;

c) emprego de alto-falantes, de telefonia com fio ou sem ele, ou de aparelhos análogos;

d) videofonografia.

Acrescenta o parágrafo único que se essa fixação for autorizada, sua execução pública, por qualquer meio, só se poderá fazer com a permissão prévia, para cada vez, do titular dos direitos patrimoniais de autor.

O dispositivo, evidentemente, compreende toda e qualquer gra vação, e não apenas, como poderia parecer, a videofonografia.

Pelo art. 35, são independentes entre si as diversas formas de utilização da obra intelectual, deixando por essa forma fora de dúvida que para cada uma delas deverá o interessado obter a indispensável licença de aproveitamento.

Cinge-se, a mesma lei, no Capítulo II, sob a epígrafe "Da representação e execução", a compendiar, arts. 73-79, os dispositivos vigentes por ocasião da promulgação do diploma em textos legais esparsos. 


\section{O contrato de representação. Natureza. Partes intervenientes}

Não é regulamentado pela Lei $\mathrm{n}^{\circ} 5.988$, que apenas prevê, genericamente, no art. 52, poderem os direitos do autor ser total ou parcialmente cedidos a terceiros.

Define-o a lei francesa, art. 43 , I, como

aquele pelo qual o autor de uma obra intelectual e seus sucessores e cessionários autorizam uma pessoa física ou moral a representar mencionada obra das condições que determinarem...

É, pois, contrato geral de representação aquele pelo qual autores, por si ou pela sua associação, confere a um empresário de espetáculos a faculdade de representar pela duração do contrato, suas obras atuais ou futuras, nas condições determinadas pelo contrato, pela lei ou pelos costumes.

Separa a alínea seguinte, dos demais, o contrato geral de representação, como tal considerado "aquele pelo qual um organismo profissional de autores confere a um empresário de espetáculos a faculdade de representar, pelo tempo de duração do contrato, as obras atuais ou futuras que constituem o repertório do mencionado órgão nas condições determinadas pelo autor ou seus interessados".

Qual a natureza do contrato de representação?

Lembra ROBERT PLAISANT ser sinalagmático: coloca o autor em relação com um empresário de espetáculos que assume a incumbência do aproveitamento da obra ou das obras. Implica cessão de direito submetida a condições determindas e subordinadas ao respeito de obrigações reciprocas:

Não se trata nem de uma associação, nem de uma venda, nem de uma cessão incondicional. Não se trata, além disso, de uma locação de serviços, porque o autor não promete ao empresário de espetáculos a criação de uma obra, mas proporcionar-lhe a fruição de uma obra composta e acabada. Poderia tratar-se de uma locação de coisas: o autor continua proprietário de sua obra e, por meio de uma remuneração, assume o compromisso de proporcionar ao empresário de espetáculos durante um certo tempo o gozo de sua coisa.

Podem todavia existir contratos de representação a título gratuito e isto seja de um lado como de outro.

A dúvida deixou de ter sentido depois que as leis começaram a considerar o de representação como um contrato típico, de prestações correspectivas, oneroso, de concessão de direitos.

Nas suas relações com o empresário de espetáculos, o autor não faz um ato de comércio, ao passo que as empresas de espetáculos são considerados comerciais. 
O compromisso do empresário tem caráter estritamente pessoal, não permitindo o art. 44, alínea $4^{\mathrm{a}}$, da lei francesa, que o transfira sem o consentimento formal por escrito do autor ou do seu representante, procurando evitar, por essa forma, especulações.

Assinala J. HEIFETZ que o contrato de representação diferencia-se do de edição, principalmente pelo seu conteúdo econômico:

"O aproveitamento de uma obra dramática, e, até certo ponto, também o de uma obra musical, verifica-se com a sua própria execução. Essas obras exercem suas influências culturais sobre grandes massas de povo, não pela leitura que delas se pode fazer, mas através de sua representação cênica, e o proveito portanto, que delas obtenham os respectivos autores, decorre não da difusão das obras, mas do seu sucesso teatral.

Do ponto de vista literário podem, assim, estas obras não ter um grande valor, embora sejam capazes, ao mesmo tempo, de constituir objeto do contrato de edição.

Outra série de obras, como pantomimas, coreografias, etc., pode, porém, constituir somente objeto do contrato de representação: o texto eventual pode não ter nenhuma difusão pela imprensa, nem valor algum cultural".

Nessa mesma ordem de idéias insiste, EUGENE POUILLET, “Traité”, pág. 738:

"O direito de representação não compreende, para 0 autor, senão o direito de autorizar a audição, a execução de sua obra; o direito de publicação compreende o direito de reproduzir a obra por meio de exemplares impressos, gravados ou manuscritos destinados a passar de mão em mão",

para daí tirar várias conseqüências, avultando a de que a cessão de um não importa a cessão de outro direito. Assim, o diretor de teatro, autorizado a representar uma obra dramática não poderia sustentar estar revestido do direito de publicá-la e, conseqüentemente, do direitc de copiá-la para executá-la.

A respeito do contrato geral de representação esclarece que, para facilitar a exploração de certas obras, os autores são levados a confiar o exercício do seu direito de representação a entidades profissionais, geralmente designados como "associações de autores", habilitados a concluir contratos gerais de representação com os empresários de espe. táculos.

O exercício do direito de autor, neste caso, torna-se coletivo.

Tratando-se de uma cessão de direitos de autor, como as demais, totais ou parciais, deverá ser feita sempre por escrito, nos termos do art. 53 da lei, que a presume onerosa. Para valer perante terceiros 
deverá ainda ser averbada à margem do registro a que se refere o art. 17.

Pelo contrato de representação e de execução cede 0 autor 0 exercício das suas faculdades de natureza patrimonial para o fim de ser representada em público uma obra dramática, dramático-musical, coreográfica, pantomímica ou outra qualquer destinada à representação, como se expressa o art. 136 da lei italiana.

As partes intervenientes são basicamente duas: de um lado o criador ou os criadores da obra, de outro lado, o concessionário. Com esta expressão, observa AMEDEO GIANNINI, Diritto di Autores, 1955, pág. 293, o legislador não entendeu aludir somente ao empresário teatral, embora seja esta hipótese mais freqüente na prática, mas também a uma entidade, uma agência teatral, uma agência comissária, uma entidade intermediária etc.

Entre as obras que possam formar objeto do contrato de representação típica não pode ser enquadrada a cinematográfica.

Não se pode afirmar, em tese geral, observa FRANCO BILE, que o conseccionário seja obrigado a pagar um correspectivo pela concessão: pode acontecer que a retribuição seja constituída somente pela obrigação de representar a obra, ou até mesmo que autor e concessionário dividam os riscos decorrentes da representação.

Com efeito o risco varia de caso para caso e é particularmente acentuado na representação de obras novas, daí resultando ser fácil compreender como nessa hipótese resulte influenciado o inteiro conteúdo do contrato.

Pelo que diz respeito à extensão da faculdade concedida pelo autor, afirma-se que, salvo convenção em contrário, o direito do concessionário limita-se à representação teatral, não se estendendo também às outras utilizações permitidas pela técnica (difusão por meio do cinema, dos discos, da televisão etc.) (PIOLA GASELLI, De SANCTIS).

Do ponto de vista contratual, o conteúdo do contrato se ocupava especificamente apenas da representação dramática, regulada nos arts. 1.359-1.362.

Mas o surto de novas invenções, o disco, o filme mudo e falado, os gravadores, o rádio e a televisão foram paulatinamente confundindo os conceitos e, ao mesmo tempo, modificando e potencializando esse velho contrato, exigindo sucessivas adaptações do texto legal, já de per si assistemático e inadequado.

\section{Obrigações e direitos do empresário}

Representam as obrigações do empresário de espetáculos a contrapartida dos direito do autor, que serão analisados em seguida. 
A primeira será requerer a aprovação do espetáculo ou da transmissão, apresentando à autoridade policial o programa, acompanhando da autorização e dos documentos necessário (art. $73, \S 2^{\circ}$ da Lei $n^{\circ}$ 5.988);

Deve fixar prazo para a representação ou execução. (art. 74) se não o fizer, permite o art. 74 ao autor, observados os usos locais, assiná-lo ao empresário.

Não pode comunicar, sem licença do autor, o manuscrito da obra a pessoa estranha à representação, ou execução.

Cumpre-lhe anunciá-la previamente ao público na forma usual, indicando o título da obra, o nome do autor, e, se for o caso, nome do tradutor ou adaptador (lei italiana, art. 138, 1).

Deve realizar a representação da obra sem adições, cortes ou variações não consentidas pelo autor. Trata-se de um dever de fidelidade bem retratado no art. 47 da lei francesa: "O empresário de espetáculo deve garantir a representação ou a execução pública em condições técnicas próprias a assegurar o respeito dos direitos intelectuais e morais do autor".

Assume ele, na observação de ROBERT PLAISANT um dever de fidelidade absoluta. Se teme que a obra não tenha sucesso por causa do estado no qual ela lhe foi apresentada, não contrate.

Reproduz em seguida estipulações das associações de direitos autorais francesas, com relação aos teatros, descendo aos pormenores relativos à afixação de cartazes e à alteração das obras. Consigna que a jurisprudência francesa aplica de maneira constante esses princípios. A obra dramática não deve ser deformada.

Dentro do critério que já consignavam o art. 25 do Decreto $\mathrm{n}^{\text {\% }}$ 18.527, de 10-12-1928, e o art. 31 do Decreto n' 5.942 de 16-07-1928, garante expressamente o art. 75 da lei pátria, ao autor, o direito de opor-se à representação ou execução que não esteja suficientemente ensaiada, bem como o de fiscalizar o espetáculo, por si ou por delegado seu, tendo, para isso, livre acesso, durante as representações ou execuções, ao local onde se realizam.

Por exceção, o autor deve manifestar uma certa tolerância e até mesmo facultar determinadas modificações secundárias quando as circunstâncias o tornem necessário.

Obrigação primordial do empresário é ainda pagar ao autor a retribuição avançada.

Dela decorre ainda a da prestação de contas.

Nos termos do art. 46, alínea $1^{\text {? }}$ da lei francesa, "O empresário de espetáculos é obrigado a declarar ao autor ou aos seus representantes o programa exato das representações ou execuções públicas e a fornecer-lhes um registro justificado de suas receitas. Deve pagar ao autor 
ou a seus representantes, nos vencimentos previstos, o montante das percentagens estipuladas".

Deve ainda permitir ao autor fiscalizar o espetáculo, por si ou por seu delegado, dando-lhe, para tanto, livre acesso, durante as representações ou execuçốes, ao local onde se realizam.

Não determinar a substituição, salvo se abandonarem a empresa, dos principais intérpretes e dos diretores de orquestra ou coro, escolhidos de comum acordo com o autor, sem consentimento deste (art. 78).

Caso tenha obtido transferência de direitos de outra empresa, ou fundir, com esta a sua, assumir os compromissos contraídos pela primeira, para com os autores, artistas e auxiliares (art. 74 do Dec. $\mathrm{n}^{\circ}$ 18.527, de 10-12-1928).

Representarem as companhias líricas, nos dias de festa nacional, óperas de autores brasileiros, com libreto na língua pátria (Dec.-Lei 4.641, 01-09-1942).

Representarem as companhias de teatro nacionais, durante suas temporadas, uma peça de autor brasileiro, em cada série de três, no mínimo (Lei no 1.565, de 03-03-1952).

O diploma encontrou resistência por parte de alguns empresários. Mas contribuiu, certamente para tornar mais conhecida a nossa produção teatral.

O Serviço Nacional de Teatro (hoje Instituto Nacional de Artes Cênicas - INACEN) não poderá conceder benefício algum a Companhia ou Empresário que não observe o aludido dispositivo.

Não há, por outro lado, como deixar de reconhecer determinados direitos ao empresário. Além daqueles que são inerentes à função que desempenha, um dos essenciais, é o de fixar o número de representações.

Salienta POUILLET a este respeito, que se o contrato não o estabelece, o diretor é o único juiz do momento em que não deve mais continuá-las. Não é provável, por outro lado, que as interrompa em pleno sucesso e quando elas estão atulhando a caixa. "Seu interesse responde por sua boa vontade."

Lembra julgado no sentido de que, em falta de compromisso especial, não se poderia admitir que o diretor de um teatro possa parar, a seu arbítrio, o número das representações mesmo em pleno sucesso e deixando o autor livre de retirar a sua peça e levá-la a um outro teatro. Deve-se interpretar o contrato tácito, intervindo entre o autor dramático e o diretor do teatro no sentido de que, no pensamento das partes, a peça deve ser levada a efeito durante todo o tempo em que ela proporcione a um e a outro receitas rendosas. Mas será sábia e conforme aos acordos implícitos a administração que abandonar uma peça que não obtém mais o favor do público. 
Tem o empresário o direito de não ver retirada a permissão dada pelo autor, não necessitando, enquanto uma obra permanece no repertório de um teatro, solicitar a autorização do autor para cada vez.

\section{Obrigậ̃es e direitos do autor}

As obrigações do autor de uma obra dramática, ou de qualquer outra que possa ser incluída no contexto do art. 73 da lei, são, mutais mutandis, as que vinculam os autores em geral, com o complemento de algumas que lhes são específicas.

São duas, essencialmente: $1^{\circ}$ ) colocar à disposição do empresário a obra literária e artística em seu corpo material; $2^{\circ}$ garantia do aproveitamento pacífico dos direitos cedidos durante toda a vigência do contrato.

$\mathrm{O}$ art. $1.359 \mathrm{CC}$ consignava uma só: não fazer alteração na substância da obra dramática sem acordo com o empresário que a faz representar.

Passou, com insignificante alteração de redação, para o art. 76 da Lei $\mathrm{n}^{\circ} 5.988$.

O dispositivo conflita com o direito de modificação consignado no art. 25, V da lei, e mesmo de arrependimento, inscrito no no VI, reconhecendo serem direitos morais do autor o de modificar a obra, antes ou depois de utilizada, e o de retirá-la de circulação, "ou de lhe suspender qualquer forma de utilização já autorizada", permitindo-lhe reconsiderar a cessão consentida. Todavia, se depois do exercício do direito de arrepender-se, o autor decide voltar a colocar sua obra em circulação, deve, nos termos da lei francesa, art. $32, \S 2^{\circ}$, oferecer prioridade dos direitos de utilização, em igualdade de condições, ao cessionário que havia originariamente escolhido.

Por parte do concessionário, ou por parte dos artistas sim, existe semelhante obrigação, consignada expressamente no Dec. legislativo $\mathrm{n}^{\circ}$ 5.492, de 16-07-1928, art. 67, caput:

Os artistas não poderão alterar, suprimir ou acrescentar, nas representações, palavras, frases ou cenas sem autorização por escrito, do autor ou sub-rogado nos direitos deste, sob pena de multa de $5 \%$ do seu ordenado mensal em favor da Casa dos Artistas, ou, na falta desta, de qualquer sociedade beneficente da classe.

O primeiro direito, não especificado na lei $\mathrm{n}^{\circ}$ 5.988, mas implícito, no que diz respeito às prerrogativas patrimoniais gerais aos criadores de todas as obras (art. 29) é o de autorizar a representação da sua peça teatral ou a execução da sua obra musical.

Constava da Lei $\mathrm{n}^{\circ} 4.970$ de 02-01-1924:

"Art. 2. - Nenhuma composição musical, tragédia, drama, comédia ou qualquer outra produção, seja qual for 
a sua denominação, poderá ser executada ou representada em teatros sem autorização para cada vez de seu autor, representante ou pessoa legitimamente subrogada nos direitos daquela".

Nos contratos de representação e execução da obra autoral são partes - lembra MILTON FERNANDES -, de um lado o criador da obra e, de outro, o usuário da peça teatral ou musical. Refere-se, especificamente, ao mencionar o usuário, ao promotor da utilização pública do trabalho artístico:

"Pela própria natureza jurídica, o direito de autor é oponivel eyga omnes. Neste sentido exerce o artista um jus prohibitionis do uso de sua criação diante de toda a coletividade.

Existe, em conseqüência, para todo aquele que pretende utilizar a produção intelectual em reuniões públicas, com intuito de lucro direto ou indireto, a obrigação de obter a outorga autoral, ou o dever de contratar. Ao autor fica o direito de celebrar ou não o ajuste pretendido, isto é, de permitir ou não o emprego de seu trabalho".

Lembra que este direito exclusivo de utilização, garantido pelo art. 153, § 25 da Constituição Federal implica necessariamente, em sentido contrário, o de não utilização, levando à conclusão de que o autor é o juiz supremo do emprego de sua obra.

"Pode permiti-lo ou não; autorizando-o, livremente fixar as condições que pretende estipular. A contratação, que para o usuário é dever, para o autor é faculdade".

Em seguida é que vem o apontado no art. 73 da Lei 5.988 , consolídando análoga norma de vários outros diplomas legais: conceder autorização para que sejam transmitidos pelo rádio, serviço de altofalantes, televisão ou outro meio análogo, representados ou executados em espetáculos públicos e audições públicas, que visem a lucro direto ou indireto, drama, tragédia, comédia, composição musical, com letra ou sem ela, ou obra de caráter assemelhado.

Desdobrando os princípios que o Projeto BARBOSA-CHAVES havia enfeixado no art. 85 , reconhece a lei 5.988 , ao autor os direitos de:

- assinar ao empresário prazo para a representação ou execução, caso não tenha sido fixado, observados os usos locais (art. 74; art. $1.360 \mathrm{CC}$ ) ;

- opor-se à representação ou execução que não esteja suficientemente ensaiada, bem como o de fiscalizar o espetáculo, por si ou por delegado seu, tendo, para isso, livre acesso, durante as representações ou execuções, ao local onde se realizam (art. 75); 
- não admitir que sem licença sua comunique o empresário o manuscrito da obra a pessoa estranha à representação, ou execução (art. 77 ; art. $1.362 \mathrm{CC}$ );

- não ver substituídos, por ordem do empresário, sem consentimento seu, os principais intérpretes e os diretores de orquestra ou coro, escolhido de comum acordo, salvo se abandonarem a empresa (art. 78);

- não ver penhorada a parte do produto dos espetáculos a ele reservada, direito que assiste também aos artistas (art. 79; art. $1.361 \mathrm{CC})$.

Por outro lado alterou, focalizando de maneira diferente, o direito que o art. 85, I, daquele projeto, reconhecia ao autor de obra lírica, dramática, teatral ou dramático-musical popular de introduzir na obra as alterações necessárias, desde que não prejudiquem a sua substância, nem diminuam o seu interesse, ressalvado o direito à indenização prévia, não as podendo fazer, sem ser de acordo com o empresário, enquanto este a esteja representando.

Não foram todavia integralmente aproveitadas outras sugestões constantes daquele Projeto:

"I. de introduzir na obra as alterações necessárias; desde que não prejudiquem a sua substância nem diminuam o seu interesse, ressalvado o direito a indenização prévia, não as podendo fazer, sem ser de acordo com o empresário, enquanto este a esteja representando; sárias;

II. de assistir aos ensaios e fazer indicações que julgar neces-

III. de fixar o prazo da representação, não podendo este ser tão restrito que contravenha as normas usuais na espécie, ou prive os resultados esperados pelo empresário;

IV. de não permitir quando se tratar de obra inédita, ainda não utilizada, que ela se torne conhecida antes da primeira apresentação, nem do seu conteúdo se utilize o empresário para os efeitos de propaganda, sem prejuízo da sua comunicação às autoridades públicas competentes".

POUILLET ainda acrescenta mais alguns direitos, como o de fixar o dia da primeira representação e o de impedir anúncios prejudiciais à sua honra, à sua reputação e à sua boa fama.

Claro que a revisão do projeto BARBOSA-CHAVES podia e devia melhorar a redação. Mas a preocupação de síntese transformou o direito do autor em obrigação de caráter negativo, na feitura que lhe deu a já mencionada lei, que lhe proíbe alterar a substância da obra, sem acordo com o empresário que a faz representar. 


\section{Recebimento e repartição dos direitos autorais - Impenhorabilidade}

Tem ainda o autor direito de receber a remuneração correspondente, caso não queira conceder a permissão a título gratuito.

Tanto pode ser estipulada numa quantia determinada, como numa participação da renda bruta, da líquida, ou qualquer outra modalidade em uso.

O Código Civil exigia três requisitos para que fossem retribuídas as execuções ou representações públicas:

1. que a obra tivesse sido publicada e posta à venda;

2. que houvesse intuito de lucro na execução ou representação;

3. que as mesmas se verificassem em reuniōes públicas.

O critério que permanece na Lei $n^{\circ} 5.988$, é dos mais infelizes. Não pode, manifestamente, satisfazer a idéia de in`uito de lucro ou de entrada paga como elemento indispensável para caracterizar a violação do direito pecuniário do autor.

$E$ pouco relevante, na verdade, a existência de um provento direto ou indireto por parte de quem executa a obra. A gratuidade não é razão para isentar quem quer que seja do pagamento devido, justamente porque assim como não há lei que obrigue ninguém a fazer caridade, não existe dispositivo que faculte quem quer que seja fazer beneficiência à custa dos eventuais proventos alheios.

O caminho certo já estava indicado pelo art. 348 do Código Penal de 1890, cominando pena de multa aos que executassem ou fizessem representar em teatros ou espetáculos públicos, com posição musical, tragédia, drama, comédia ou qualquer outra produção, seja qual for a sua denominação, sem consentimento, para cada vez, do dono, do autor.

O advento do Código Civil assinala um sensivel recuo na proteção de direito de autor de execução musical, repercutindo a fundo, ainda hoje, no desenvolvimento de nossa produção artística, pois, tolhendo aos autores a possibilidade de auferirem rendas da maior parte das execuções de suas obras, não poderia servir de estímulo para a produção musical, quase impunemente saqueada.

A legislação posterior, Decreto $\mathrm{n}^{\text {9 }} 4.790$, de 02-01-1924, nada mais fez senão retomar o mesmo conceito, no art. $2^{\circ}$ já transcrito.

Para prevenir, tanto quanto possivel, a realização de espetáculos públicos não acompanhados da devida retribuição, autoriza 0 art. $6^{\circ}$ do Decreto $n^{\circ}$ 4.790, de 02-01-1924, ao titular do direito de autor requerer a apreensão das receitas brutas da representação ou exibição, se a execução se fizer sem a autorização, para cada vez, de seu autor, representante ou pessoa legitimamente sub-rogada nos direitos da- 
quele, mediante os requisitos e formalidades indicados no parágrafo único.

Mas a evolução da técnica, divulgando meios como o toca-discos, a radiodifusão, a televisão, cassetes, etc. que excluem a necessidade de uma reunião de espectadores, num determinado local e numa hora certa, para participarem da execução de uma obra, tornaram obsoleto esse dispositivo. Daí ter vindo o parágrafo único tanto do art. 26 do Decreto $\mathrm{n}^{\circ}$ 5.492, de 16-07-1928, como do art. 47 de seu Regulamento, Decreto $\mathrm{n}^{\circ}$ 18.527, de 10-12-1928, com disposição idêntica, definir o conceito e ampliar o amparo já outorgado, considerando realizadas com intuito de lucro "quaisquer audições musicais, representações artísticas ou difusões radiotelefônicas em que os músicos, executantes ou transmitentes, tenham retribuição pelo trabalho".

Já vimos nada justificar que alguém com direito de desfrutar a execução apenas pessoalmente, ou dentro do limitado círculo de seus parentes e amigos, em seu lar ou local restrito venha a transmitir um espetáculo dessa natureza a um grupo mais extenso de pessoas.

Entra em jogo, nessa hipótese, o fator de publicidade, impondo a obrigação de retribuir o autor cujas obras são executadas, não se concebendo disponha alguém, sem a devida licença, do que não é seu.

Abrindo uma exceção ao princípio geral que manda ocorra o pagamento dos direitos autorais anteriormente ao seu aproveitamento econômico, determina o $\S 3^{\circ}$ do art. 73 da Lei 5.988 que quando se tratar de representação teatral o recolhimento seja feito no dia seguinte ao da representação, à vista da freqüência ao espetáculo.

Tem sido realçado o duplo inconveniente da fórmula. Por um lado, não poderão os criadores das peças aproveitadas furtar-se à contingência de autorizar a representação antes de receberem seus direitos autorais. Por outro, presta-se a abusos principalmente por parte de circos e companhias teatrais ambulantes, que percorrem as pequenas cidades do interior. Terão que sofrer os representantes das sociedades autorais o desaponto de freqüentemente não encontrar ninguém de quem cobrar o devido, "no dia seguinte" ao da representação.

É o que acentua CLÃUdIO DE SOUZA AMARAL, Dos Antecedentes Históricos às Implicações Atuais da Nova Lei sobre Direito Autoral, Revista do Direito Autoral, Rio de Janeiro, SBAT, n 9, 1973. Antes de mais nada, porque os teatrólogos ficarão obrigados a conceder a licença da representação anteriormente ao pagamento de seus direitos autorais, espécie de licença compulsória, que conflita com o regime geral. Em segundo lugar, haverá sempre o risco de, "no dia seguinte" àquele da representação, não receber o titular do direito o que lhe é devido, o que ocorrerá principalmente nos casos de companhias teatrais itinerantes pelo interior do País.

Problemas delicados dá lugar a repartição dos direitos autorais em matéria de obras dramático-musicais. 
Tratando-se de trabalho em colaboração divisível, não cabe o disposto no art. $653 \mathrm{CC}$., que apenas na hipótese contrária atribui a ambos os colaboradores, não havendo convenção em contrário, direitos iguais.

A Lei 5.988 no texto correspondente, que é o art. 31, não lhe reproduziu a menção a essa igualdade.

Teria revogado o Código, quanto a esse particular?

Entendemos que não, pois a nova lei não contém qualquer norma incompatível com o princípio, única hipótese em que o art. 134 tem por revogadas as disposições anteriores.

Acrescenta o art. 655 CC., também não reproduzido, mas que nem por isso deixa de estar em vigor, em virtude das mesmas razões, que o autor de composição musical, feita sobre texto poético, pode executá-la, publicá-la ou transmitir o seu direito, independente de autorização do escritor, indenizando, porém a este, que conservará direito à reprodução do texto sem a música.

Ora, a obra dramático-musical é divisível. Se não houver acordo, como serão computados os direitos autorais dos compositores da música, frente aos criadores da letra?

Modificando o critério igualitário da lei italiana de 1925, a atual, de 1941, outorga, no art. 34 ao autor da parte musical o exercício dos direitos de aproveitamento econômico, ressalvados, entre as partes, os direitos derivados da colaboração, aditando que

O benefício do aproveitamento econômico será distribuído em proporção ao valor da contribuição literária ou musical respectiva.

Nas óperas considerar-se-á que o valor da parte musical representa três quartas partes do valor da obra em conjunto.

Nas operetas, melopéias, composições musicais com letra, danças e balé, considerar-se-á igual o valor de uma e outra contribuição.

Julga HERMANO DUVAL, Obra dramático-musical (óperas e revistas), Repertório Enciclopédico do Direito Brasileiro, Rio, Borsoi, vol. 35, sem data, págs. 16-20, não dever ser igual, entre nós a repartição do lucro, à vista da prevalência que o art. 655 dá à parte musical.

Invocando NICOLA STOLFI, Il Diritto di Autore, 1932, vol. I, 497, propõe $2 / 3$ para a música e $1 / 3$ para a letra, ou consistir na indenização que for atribuída ao escritor pelo compositor em acordo amigável ou por via de arbitramento judicial.

A importância maior de suas considerações é a conclusão de que cabe o exercício do direito pecuniário, com reserva do direito moral do escritor, indiscutivelmente ao compositor, que assim poderá auto- 
rizar sua adaptação ao cinema, rádio e televisão, independentemente do consentimento do literato, mas sujeito a responder por perdas e danos a favor deste.

Procurando assegurar o recebimento dos direitos devidos, vale-se a nossa lei, tradicionalmente, de três critérios, que foram adotados no já transcrito $\S 2^{\circ}$ do art. 73 :

1. aprovação do programa, acompanhada, de:

2. autorizações dos: a. autor;

b. intérprete ou executante;

c. produtor do fonograma; bem como do

3. recibo de recolhimento do valor dos direitos autorais em agência bancária ou postal, ou documento equivalente.

$\mathrm{O}$ art. 89 da Lei 5.988 garantiu a impenhorabilidade da parte do produto dos espetáculos reservada ao ator e aos artistas.

Lamenta MILTON FERNANDES, depois de frisar quão parco foi o legislador de 1973 com o autor, ao disciplinar a manifestação de sua vontade nos contratos de representação e execução públicas da obra intelectual, especialmente ao manter o intuito de lucro como requisito para a outorga da licença, que os direitos patrimoniais não tivessem tido a mesma proteção oferecida ao direito moral.

O fato do próprio autor de uma peça teatral assumir a função de encenador e de desempenhar ainda a de ator, será motivo para que não receba os correspondentes direitos autorais?

A essa interessante questão deu, com todo acerto, resposta negativa a Primeira Turma do Supremo Tribunal Federal, no Recurso Extraordinário $n^{\circ} 68.190$, do Maranhão, relativo a uma ação proposta pela Sociedade Brasileira de Autores Teatrais contra o Grêmio Lítero Recreativo Português que se eximia do pagamento sob pretexto de que, além do autor participar do elenco, não conseguira a apresentação o lucro esperado.

Frisou o relator do acórdão unânime de 09-04-1973, Ministro ALIOMAR BALEEIRO (DJ da União de 25 de maio seguinte, pág. 3.626) que apenas a inclusão de cláusula contratual expressa em contrário poderia levar a conclusão diferente da ementa:

"Direitos Autorais - $\mathrm{O}$ fato de a peça teatral ter sido encenada pelo próprio autor, como ator e executor, mediante remuneração por espetáculo, não exclui seu direito correspondente à propriedade literária e musical, se o contrário não foi estipulado. O recurso extraordinário não tolera reexame da interpretação de cláusulas contratuais".

Outra prerrogativa de ordem material é reconhecida pelo art. 70 da Lei 5.988 tanto ao autor como aos artistas: a impenhorabilidade 
da parte que lhes cabe do produto dos espetáculos, que o art. 1.361 do Código Civil reconhecia apenas ao primeiro.

Acrescenta ROBERT PLAISANT que para ter a possibilidade de passar com os usuários contratos gerais (chamados, conforme o caso, tratados, contratos-tipo, assinaturas, etc.), as associações de autores tomam duas ordens de providências:

$1^{\circ}$ - Antes de mais nada, para constituir seus repertórios, elas exigem dos autores ou dos cessionários a "declaração" ou "depósito" de suas obras conforme processos particulares a cada organismo. Esses depósitos têm igualmente a vantagem de fixar as partes que cabem a cada um dos autores de uma obra em colaboração e aos cessionários eventuais e, de outro lado, proporcionar provas em caso de plágio ou de contestação.

$2^{\circ}$ - Elas proibem a seus membros tratar fora da sociedade.

"Associações de autores" - acrescenta - "não são sempre cessionários do direito de exploração. No que concerne à associações de autores e compositores dramáticos, o autor ou compositor não lhes aduz senão a administração dos direitos de representação sobre suas obras dramáticas e, conseqüientemente, conserva sempre e em qualquer lugar, nos limites dos tratados gerais dessas associações o direito de proibir a representação de sua obra.

Por outro lado, no que diz respeito às associações de autores de música, o autor concede o direito de autorizar ou de proibir a execução ou a representação pública de suas obras, desde que criada".

Determina o art. 74 do Decreto 18.527 , de 1928, caso uma empresa transfira os seus direitos a outra ou se funda com esta, assuma a segunda os compromissos contraídos pela primeira, para com os autores, artistas e auxiliares.

\section{Participação de artistas remunerados e intuito de lucro}

A referência a artistas remunerados constante do $\S 1^{\circ}$ do art. 73 está relacionada com o intuito de lucro, direto ou indireto a que faz alusão o caput do dispositivo, já estudado em páginas anteriores.

Observa PEDRO VICENTE ROBBIO que ao mesmo tempo que o conceito de publicidade adquire elasticidade mais acentuada, o requisito patrimonial e lucrativo é abrandado e estendido a formas indiretas e não unicamente patrimoniais, de vez que, no art. 80 , VIII, o Dec.-Lei $\mathrm{n}^{\circ}$ 2.049, de 24-01-1946 fala em vantagens ou lucro, obtidos direta ou indiretamente.

É exclusivamente com relação aos espetáculos públicos "ao vivo" que prevalece o art. $73, \S 1^{\circ}$ da Lei $n^{\circ} 5.988$, ao considerar a remu- 
neração de artistas como elemento caracterizador da obrigação do pagamento dos direitos autorais.

Quando houver transmissão de um espetáculo por qualquer meio, prevalecerá o caput do mesmo artigo, exigindo a necessária autorização, prevalecendo pois, a lição de que o autor de obra musical tem interferência assegurada em todas as execuções de sua obra que se realizem fora do ambiente familiar e doméstico habitual do respectivo promotor e que, direta ou indiretamente, lhe possam proporcionar vantagens ou lucro, presumindo-se, ipso facto, a intenção lucrativa sempre que a execução for confiada a pessoa ou pessoas retribuídas.

Mas, lembrando-se que o art. 52 da Lei $n^{\circ} 5.988$ considera a possibilidade de os direitos do autor serem total ou parcialmente cedidos a terceiros, por ele ou por seus sucessores, a título universal ou singular, pessoalmente ou por meio de representante com poderes especiais, chega-se à conclusão de que poderão também os sucessores, adquirentes ou cessionários tornarem-se titulares desses direitos, passando então por sua vez, a permitir a terceiros o aproveitamento da obra, permissão essa que, pelo nosso sistema, tem que ser prévia à execução.

Isto ocorreu pelo sistema vigorante desde 1928 , em virtude do Dec. $\mathrm{n}^{\circ} 18.527$, de 10 de dezembro, confirmado pela Lei $\mathrm{n}^{\circ} 5.536$, de 21-11-1968, que dispõe sobre a Censura de Obras Teatrais e Cinematográficas, cria o Conselho Superior de Censura e dá outras providências, e compendiado no $\S 2^{\circ}$ do art. 73 da Lei 5.988 já aludido:

Ao requerer a aprovação do espetáculo ou da transmissão, o empresário deverá apresentar à autoridade policial, observando o disposto na legislação em vigor, o programa, acompanhado da autorização do autor, intérprete ou executante e do produtor de programas, bem como do recibo de recolhimento em agência bancária ou postal, ou ainda documento equivalente em forma autorizada pelo Conselho Nacional de Direito Autoral, a favor do Escritório Central de Arrecadação e Distribuição, de que trata o art. 115, do valor, dos direitos autorais das obras programadas.

Reconhecendo que todas as execuções ou irradiações de composições musicais, quando levadas a efeito em reuniões públicas, contém implícita a presunção de que obedecem a intenção lucrativa, o Dec. $\mathrm{n}^{\circ}$ 5.492, alterando o critério da entrada paga do art. $657 \mathrm{CC}$, confirmado pelo Dec. 4.790 , de 1924, submeteu, no art. 26, à prévia autorização dos autores as execuções ou irradiações de composições musicais quando realizadas com intuito de lucro, em reuniões públicas, partindo do pressuposto de obedecerem à intenção lucrativa decorrente de músicos ou os que transmitem a execução receberem retribuição pela atividade desenvolvida. Uma vez que aí já não se cogita em audição retribuída diretamente, sendo suficiente que se execute música em local público com pagamento de entrada, seja a música o principal ou o acessório, 
estaria o aludido artigo do Código Civil derrogado pelo decreto 4.790, que também introduziu o conceito de publicidade, que o Código Civil ignorava, por ser desnecessário ao seu critério rigidamente econômico e utilitário.

Embora também não se refira ainda expressamente à obra cinematográfica, o art. $2^{\circ}$ do Dec. 4.790 de 2 de janeiro de 1924 inclui evidentemente esse tipo de produção, ao dispor que "nenhuma composição musical, tragédia, drama, comédia ou qualquer outra produção, seja qual for a sua denominação, poderá ser executada ou representada em teatros ou espetáculos públicos, para os quais se pague entrada, sem autorização, para cada vez, de seu autor, representante ou pessoa legitimamente sub-rogada nos direitos daquele".

Com mais precisão, o art. 27 do decreto 5.492 de 16 de julho de 1928 estatui: "Os proprietários ou empresários de quaisquer estabelecimentos de diversões, salões de concerto ou festivais são responsáveis pelos direitos autorais das produções aí realizadas".

Como não haverá praticamente caso em que, em execuções dessa natureza, não haja retribuição de músicos, oupelo menos, de operadores, a conclusão é que já na vigência do Dec. 5.492 dependia da licença do autor a generalidade das execuções públicas.

\section{y Subvenções, ajuda de custo, etc., integram a renda bruta da peça teatral}

Renda bruta de um espetáculo teatral é a quantia resultante de todo produto operacional que constitui receita; o total recebido. Se desse montante deduzirmos as despesas relacionadas com a própria realização do espetáculo: impressão de bilhetes e dos programas, propaganda, consumo de energia elétrica, taxas, impostos, pagamento de empregados, etc., teremos a renda líquida.

Mas, na prática, a coisa não se passa com tanta simplicidade.

Como é sabido, nem sempre o público acode aos espetáculos teatrais, fenômeno que vem se acentuando nos últimos decênios, após a difusão cada vez maior dos cinemas e dos espetáculos transmitidos pelo rádio e pela televisão.

Reconhecendo, porém, a grande importância que os espetáculos teatrais representam em prol da arte e da cultura, entidades existem que, amparam iniciativas dessa natureza, por meio de subsídios, que podem ser separados em duas grandes categorias:

Subvenções por entidades públicas, que tanto podem ser Federal (provindas do Serviço Nacional de Teatro, SNT), como Estaduais (Secretaria de Cultura ou órgão equivalente), ou Municipais.

São regulamentadas por meio de contrato, através do qual o órgão público costuma exigir uma redução de pelo menos dois terços do 
preço normal do ingresso, ou quando o auxílio se destina a cobrir todas as despesas, mediante proibição terminante de venda de ingressos.

$\mathrm{Na}$ primeira eventualidade, os órgãos públicos adquirem a totalidade dos ingressos da bilheteria de um determinado espetáculo, ao preço normal, revendendo-os depois, em bilheterias volantes, sob o patrocínio desse mesmo órgão oficial, a um preço correspondente a cerca de um terço daquele.

Alguns órgãos oficiais propõem-se gratificar com um prêmio extra os empresários da peça cujos ingressos alcancem grande procura, p.ex. mais de 2.000 , recebem mais uma quantia suplementar por cada ingresso excedente àquele limite.

Complementos que se inserem naturalmente no preço de entrada, no caso de subvenção por entidades públicas, oferecem ainda a característica de provirem, em última análise, das contribuições oriundas do pagamento de taxas de impostos que incumbem a todos os cidadãos: é bem de ver que destinando-se a proteger e amparar o espetáculo teatral em si, não há razão plausível para que redundem em benefício exclusivo dos empresários, que embolsam tais importâncias como se a eles fossem destinadas, quando constitui um imperativo de justiça não excluir de uma participação das mesmas os autores das peças, sem os quais não haveria representações, nem teatros, nem, evidentemente, empresários.

As subvenções por entidades particulares são feitas geralmente mediante a compra pura e simples do espetáculo teatral, oferecidas em seguida as entradas aos funcionários, aos clientes, ou ao público em geral, quando se tratar de publicidade dos produtos das empresas interessadas.

Integrando-se no próprio contexto do valor da entrada, participam da renda bruta de bilheteria.

Nesse e em outros setores, principalmente entre nós, por falta de diretrizes uniformes coerentes, acumularam-se nos últimos anos dúvidas, malentendidos e controvérsias, sempre em grave prejuízo dos autores.

Na França ao que informava em agosto de 1974 Intersocietés Bullettin de liasion et d'information des sociétés conféderés et de la Sécretarie Générale, Cisac n ${ }^{\circ}$ 11, os Centros Dramáticos e Casas de Cultura reconhecem que as particulares condições de aproveitamento dos estabelecimentos de Ação Cultural, graças a subvenções que possibilitam localidades baratas bem como um aproveitamento calculado antecipadamente, não devem impedir que o autor receba a justa remuneração por seu trabalho. Considera-se pois normal que um mínimo superior às autênticas possibilidades de lucro seja reclamado para os autores e aceito pelos diretores. Esse mínimo é fixado em cada caso 
de comum acordo entre autor ou a Associação de Direitos Autorais e o Diretor do Centro ou Casa de Cultura interessado.

Semelhante disposição já figurava no preâmbulo do contrato que o SACD celebrou em 1973 com as companhias de animação cultural francesas, belgas e suiças e permitiu aumentar consideravelmente as arrecadaçōes dos grupos de animação cultural, sem obstáculos por parte dos usuários.

Refere DJALMA BITTENCOURT, Rev. de Teatro $n^{\circ} 380$, MarçoAbril 1971, págs. 23 e 24 que as Sociedades de Autores e Compositores da França, tanto a SACEM, que controla os direitos autorais de execuções musicais, quanto a SACD, que tem o seu cargo a defesa econômica dos direitos dos autores teatrais, dos elementos essenciais como receita bruta:

a) a venda dos bilhetes, inclusive as assinaturas;

b) as somas recebidas pela locação de lugares ou pela reserva de mesas;

c) os suplementos recebidos por ocasião de permuta de lugares;

d) a venda de programas ou de bilhetes de tômbola, sempre que eles derem direito à entrada, servindo assim de bilhete de ingresso.

A essa receita bruta se ajunta, ainda, uma receita presumida, representada pelos convites, cadeiras cativas ou entradas de favor quando excedam de $5 \%$ do total de lugares vendidos e calculados ao prêmio médio das entradas.

As outras receitas são constituídas por quaisquer meios não indicados acima e, em particular, por:

a) venda de consumação ou "buffet", na sala de espera, compreendida na área que dá acesso o bilhete de entrada;

b) a venda de programas, surpresas de bolso, insignias, etc., quando em proveito do organizador do espetáculo;

c) a venda de bilhetes de tômbola, quando realizada na sala e desde que tenha relação com o organizador do espetáculo;

d) as barracas de jogo.

Considera o articulista nada ser mais justo do que associar o autor à vida de sua obra. Se o negócio da representação redunda num desastre completo de bilheteria, o autor é o maior prejudicado porque dificilmente conseguirá colocar uma segunda peça. O empresário jamais se esquecerá de prejuízo que teve. $\mathrm{E}$ todos os outros empresários esquecerão imediatamente os sucessos anteriores desse mesmo autor para conservarem na memória apenas o último fracasso. 
Refere o caso de um empresário que comprou por quantia fixa uns tantos espetáculos a uma Companhia de São Paulo e levou-a a excursionar entre o Triângulo Mineiro e Goiás, conseguindo resultados de bilheterias muito superiores ao total da quantia paga à Companhia. $\mathrm{E}$ ficou muito surpreso quando a SBAT lhe exigiu os direitos autorais relativos à diferença obtida entre a quantia paga à Companhia e aquela acusada pela bilheteria de cada espetáculo.

O caso dos sócios cotistas obrigou a recorrer ao poder judiciário. Uma empresa contrói um teatro à base de cotas e promete aos cotistas ingresso gratuito durante dez ou vinte anos, etc. Uma Companhia que vá ocupar num teatro nessas condições, terá ônus de milhares de ingressos, por mês, concedidos pela Empresa aos seus sócios cotistas. E o mais curioso é que os sócios cotistas poderão dar ou vender o seus ingressos. E o autor da peça? Não teria direito a coisa alguma, porque a Empresa deu uma casa de espetáculo à Cidade... Mas o patrimônio representado pelo imóvel-teatro, - ah! este pertence à Empresa, logicamente !

Pleiteou a Sociedade Brasileira de Autores Teatrais, SBAT o recebimento de percentagem sobre a subvenção recebido por Paulo Nolding Produções Artísticas, conforme comprovante.

Reformando sentença de primeira instância, decisão unânime da $2^{\text {a }}$ Câmara Cível do Tribunal de Alçada da Guanabara, apelação $\mathrm{n}^{\text {? }}$ 25.507, reconheceu à unanimidade, por acórdão de 08-11-1973, Rev. de Teatro $\mathrm{n}^{\circ} 396$, novembro-dezembro desse ano, págs. 23 e 24, acompanhando o voto do relator, Juiz FABIANO DE BARROS FRANCO, que o contrato determina que os autores da peça teriam direito à percepção de $10 \%$ sobre toda quantia recebida de entidades públicas ou particulares, direta ou indiretamente em espécie ou representada por auxílio-viagem etc. desde que obriguem a empresa a "fornecer ingresso gratuito ou a realizar um ou mais espetáculos gratuitos ou com redução de preços". Do próprio edital do Conselho Estadual de Cultura, que estabeleceu as condições para o recebimento de auxílio financeiro, consta item que a empresa fornecerá ao Departamento de Cultura "localidades até o valor do auxílio, em dias de menor freqüência a fim de serem distribuídos por estudantes ou professores" e o número de representações populares, $52 \mathrm{em} 135$ indica que os preços foram reduzidos para atender, também, às condições do edital.

Não havia, pois, como fugir às condições do contrato, que faz lei entre as partes desde que não contrarie disposição legal.

Na Alemanha Federal foi constituída uma comissão paritária de inquérito, composta por quatro membros da Associação de Teatros Alemães, dois autores dramáticos e dois editores cênicos para examinar os dados relativos a uma reforma do sistema de retribuição para os direitos de representação.

Estabeleceu-se um "modus vivendi" no sentido de que a maioria dos contratos celebrados com os 195 teatros subvencionados prevê 
uma arrecadação numa base de $12 \%$ sobre os ganhos de bilheteria. Ao mesmo tempo está prevista uma "garantia" (isto é, uma arrecadação mínima) ou por representação ou por uma série de representações: de 150 a 1000 marcos por representação para as obras dramáticas; de 500 a 3000 marcos por um sarau de ópera ou opereta.

Tais quantias são as mínimas e correspondem a uma arrecadação de 12 a $14 \%$ na conformidade da afluência do público sobre os ganhos reais de bilheteria.

O sistema apresenta, segundo DANIEL ROCHA, $O$ Direito de Autor em Companhias Subvencionadas, Rev. de Teatro, janeiro e fevereiro de 1977, as seguintes características:

"1. Os teatros subvencionados garante para cada lugar ocupado por um convidado uma soma fixa como direito de autor para cada espectador.

2. Essa soma se calcula conforme as despesas do teatro com seus artistas. Ela varia entre 1,00 e $2,70 \mathrm{DM}$ para as obras musicais, e entre 0,75 e 1,50 DM para os dramas e as comédias, por espectador, isto é, as grandes óperas (Berlim, München, Hamburg) pagam 2,70 DM para cada espectador, os grandes teatros (Berlim, München, Hamburg, Dusseldorf, Colônia) pagam 1,50 DM, os pequenos teatros de província pagam por exemplo 1,00 e $0,75 \mathrm{DM}$ respectivamente, não importando que o lugar seja vendido a preço normal, a preço reduzido, ou que seja oferecido de graça.

3. A soma desses direitos de autor em forma de garantia para cada lugar ocupado deve ser a equivalente pelo menos a $12 \%$ da renda da bilheteria. Caso a soma supere $18 \%$ da receita de bilheteria o excedente não será contado.

4. De dois em dois anos, esse sistema será objeto de um exame e se for necessário, sofrerá uma adaptação aos índices de salários e preços.

5. Esta prática incide somente sobre os teatros subvencionados pela administração pública (federal ou municipal).

Os teatros particulares (por exemplo o "Theater am Kurfurstendamm", e a "Romodie" de Berlim) e as tournées teatrais continuam pagando os direitos autorais de $10 \%$.

De acordo com o novo sistema, conclui os membros do "VERBAN DEUTS CHERBÜHNEN VERLEGER" não fazem mais seus cálculos na base das receitas de bilheteria, mas sobre o total das receitas auferidas pelos teatros das diversas fontes.

Tal ponto de vista encontrou consenso no Conselho Internacional de Autores e Compositores Dramáticos da Confédération Internationale des Sociétés d'Auteurs et Compositeurs, CISAC. Reunido em Atenas, no dia 27-09-1977, considerando que da política de subvenções 
em favor dos teatros em rebaixar o preço das entradas com a finalidade de facilitar o maior acesso possivel ao espetáculo teatral, que redunda numa considerável diminuição de sua remuneração, com à criação dramática contemporânea.

Estimando que compete às Associações de autores dramáticos buscar com energia e urgência soluções, baixou, sob o título "Participação das subvenções na remuneração dos atores dramáticos", recomendação de que as Associações realizem, em harmonia com as entidades gremiais ou sindicatos de autores de seus paises, diligências para chamar a atenção dos Poderes Públicos sobre o problema, que exige pronta solução, pois do contrário poderiam ocorrer graves conseqüências para o futuro de uma profissăo já ameaçada, e, de maneira especial, que se inclua no montante relativo aos rendimentos de direito de autor, não somente os ingressos de bilhete, incluindo o produto dos descontos, mas também a totalidade das subvenções concedidas, seja pelos Poderes Públicos (Estados, Câmara de Deputados, Municípios, etc.) ou por organismos particulares.

No Brasil, a SBAT introduziu, nos contratos de autorização para a representação de obras teatrais por seu intermédio, uma cláusula em virtude da qual a direção do teatro lhe reconhece expressamente uma participação de $10 \%$ sobre "toda e qualquer quantia paga por entidades públicas ou particulares, ou pessoa física, a título de ajuda, subvenção ou a qualquer outro título, em espécie ou representada por auxílio de viagem, de estada, alojamento, passagens, ou quaisquer outros benefícios, desde que tais ajudas ou subvenções obriguem a EMPRESA a fornecer ingressos gratuitos ou a realizar um ou mais espetáculos gratuitos ou com redução de preço ou, ainda, quando tais recebimentos se refiram a espetáculos já realizados".

Posta em dúvida a validade de semelhante cláusula, foi ela admitida por decisão de primeira instância de 16-04-1973 do Rio de Janeiro, confirmada por acórdão de 08-11-1973 do Tribunal de Justiça.

\section{A venda de "posters" e programas ilustrados (e que transcrevam trechos da peca teatral) fazem parte, também, da renda bruta da peça}

A pequena margem de remuneração concedida aos autores, a facilidade com que a parcela que lhes é devida é subtraída a uma fiscalização rigorosa, e as múltiplas modalidades de eludí-la, constituem um verdadeiro desafio que tanto o legislador como o magistrado precisam se esforçar por resolver de maneira satisfatória.

A venda de "posters" e de programas da peça, por ocasião do espetáculo, representa uma renda indireta de bilheteria, podendo atingir quantias consideráveis, que, não se precaverem os autores ou seus representantes legais, beneficiarão exclusivamente os empresários, ou terceiros, sem que os autores - insista-se, parte fundamental e razão 
de ser de todo o mecanismo - delas participem ou sequer venham a tomar conhecimento.

Os "posters", impressos em geral no formato de 1,00 por $0,60 \mathrm{~m}$, retratando cenas da peça, não seriam evidentemente vendidos, não dessem lucro, além de constituir precioso veículo de propaganda.

Os programas, em média com 10 páginas, reproduzem fotos de cenas de peça, com biografia do autor, indicação do elenco e outros pequenos textos. Normalmente explorados pelos empresários, contém aproximadamente dois terços de suas páginas de ampla publicidade comercial, sendo vendidos dentro do teatro.

Sobre as importâncias, tanto relativas a subvenções pagas direta ou indiretamente pelo Poder Público ou por empresas privadas, como as provenientes de venda de posters, programas, flâmulas, medalhas, imagens, bonecos, etc., alusivas à peça teatral, têm que incidir os direitos de autor.

A razão é sempre a mesma.

A criação intelectual do autor da peça é que movimenta não só o organismo principal, que, no caso, é a própria realização da peça teatral, como, ainda, todos os maquinismos e válvulas suplementares ou complementares que atuam em função dela, seu fundamento, sua própria razão de ser.

A simples consideração de que, se não existisse a peça, jamais haveria como cogitar de tais posters ou de tais programas, convence de que, assim como o autor participa de uma percentagem sobre o principal, não há razão para que não compartilhe também dos complementos daquela criação.

Não se trata senão a aplicação do princípio, universal do reconhecimento da participação do autor em todas as manifestações, e, pois, em todos os proventos que a sua criação possa proporcionar, e que a Lei $n^{\circ} 5.988$ sansiona energicamente:

"Art. 29 Cabe ao autor o direito de utilizar, fruir e dispor de obra literária, artística ou científica, bem como o de autorizar sua utilização ou fruição por terceiros, no todo ou em parte".

Publicar e multiplicar fotos da montagem da peça, transcrever passagens dela, para fins comerciais, com evidente intuito de lucro, não é fruição por terceiros, de parte da obra? Não é ao seu autor que esse dispositivo reserva a exclusividade de utilizar e fruir, e quando não queria fazê-lo pessoalmente, "dispor" de sua obra e autorizar sua utilização ou fruição por terceiros?

Como duvidar, então, que semelhante forma de aproveitamento deve ser autorizada pelo titular, e que, ainda quando sua permissão possa ser presumida tácita, a ele deve reverter, proporcionalmente, uma parte dos rendimentos? 
Têm, portanto, os autores, direito a uma percentagem sobre todo e qualquer rendimento, direto ou indireto, que a obra possa proporcionar-lhes.

Temos, de resto, uma primeira luminosa manifestação jurisprudencial confirmadora de tudo quanto ficou exposto.

A Sociedade Brasileira de Autores Teatrais - SBAT, representando os tradutores da obra de S. I. WITKIEWICZ, "Mãe", contratou com Tereza Rachel Produções Artísticas Ltda. a representação teatral da mesma, mediante o pagamento de direitos autorais de $10 \%$ sobre a renda bruta de cada espetáculo ajustado, na conformidade da seguinte cláusula:

"A Empresa reconhece expressamente à SBAT, independentemente de qualquer juízo ou interpretação, a participação percentual de $10 \%$ (dez por cento) sobre toda e qualquer quantia por ela recebida ou a receber, de entidades públicas ou particulares, direta ou indiretamente, em espécie ou representada por auxílio de viagem, de estada, alojamento, que tais entendimentos obriguem a EMPRESA a fornecer ingressos gratuitos ou a realizar um ou mais espetáculos, gratuitos ou com redução de preço, ou, ainda, quando tais recebimentos se refiram a espetáculos já realizados".

Vindo a saber que a referida firma comercial recebeu do Estado da Guanabara uma subvenção de $\mathrm{Cr} \$ 72.000,00$, como auxílio para montagem dessa peça teatral, sob o compromisso de realizar temporadas a preços populares e de distribuir ingressos até o valor da subvenção, em dias de menor freqüência, o que realmente ocorreu, deixando, no entanto, de pagar os direitos autorais, na forma pactuada, moveu-lhe ação ordinária para cobrar-lhe Cr\$ 7.200,00.

Defendeu-se a requerida, sustentando ser nula tal cláusula pois, inserta no instrumento impresso, desde 1964, jamais se teria executado; assinado o contrato sob esse clima de confiança, estaria configurada a simulação, e a autora seria, assim, carecedora da ação.

Ainda que inválida não fosse, a subvenção dada pelo Governo da Guanabara teria por fim incrementar a divulgação da cultura, certo que a participação do autor, nessas subvenções, foi debatida e negada.

Afinal, a subvenção seria para montagem da peça. Teria finalidade de compensar os riscos do empresário, cuja fortuna é incerta, ao contrário da do autor que ganha sempre, independentemente do sucesso, da sua produção intelectual.

Em sucinta, mas precursora sentença de 16-04-1973, o então M. Juiz em Exercício na 14a Vara Cível do Estado da Guanabara, ONURB COUTO BRUNO (Rev. de Teatro de novembro e dezembro de 1973, págs. 27 e 28), repeliu a defesas, demonstrando nada ter de simulado o ato. A ré havia firmado um contrato para representação 
da obra, obrigando-se a pagar direitos autorais sobre tudo quanto recebesse e que pudesse repercutir na arrecadação da bilheteria.

Nem mesmo a reserva mental, não referida expressamente no Código, mas que pode considerar-se abrangida pelo $n$. II, do artigo 102, estava configurada, porque nenhuma intenção de não exigir c cumprimento da cláusula, conhecida da ré, houve por parte da autora, que, ao contrário, tem exigido o percentual, nas mesmas condições, de outros empresários.

"Irrelevante ao deslinde da causa que a Comissão Especial de Teatro não tenha atribuído, ao autor da obra, parte da subvenção. Se o tivesse feito, certamente a cláusula $\mathrm{n}^{\circ} 6$ não existiria.

Ela foi incluída no contrato padrão exatamente para proteger o direito do autor de uma indireta expropriação da sua propriedade intelectual, frustrando o Estado, através de subvenção aos empresários, as rendas sobre as quais vai incidir o percentual relativo ao direito autoral.

$\mathrm{E}$ a incidência da alíquota correspondente a esse direito não se condicionou à apuração de qualquer resultado econômico, em face da subvenção, motivo por que era dispensável a prova pericial perseguida pela ré".

$\mathrm{O}$ último fundamento em que se abroquelava a ré podia ser muito válido como um argumento do que as partes deveriam ter contratado. Não lhe cabia, porém, julgar em face do que deveria ser, mas compor o conflito à luz da norma em que se converteu, para os litigantes, a cláusula $n^{\circ} 6$ do contrato.

Se a subvenção, em todo seu quantum, repercutiu na renda; se a renda é a base da remuneração do autor, pela exploração da sua propriedade intelectual, não restava a menor dúvida de que os $10 \%$ devem incidir sobre a contribuição dada pelo Estado.

"Aliás, essa contribuição, se teve em mira favorecer a divulgação da cultura, não foi, às escâncaras, o seu objetivo, prejudicar o autor, que é o núcleo de onde essa cultura se irradia.

Embora se projete muito mais a imagem do autor, do técnico, do especificador, do tradutor, eles todos seriam nada sem o gênio criador do autor da obra literária, artística e científica.

Essa obra, muito ao contrário do que insinuou a ré, na audiência, não tem pátria. Ela é patrimônio do seu criador, que tem direito exclusivo de lhe ligar o seu nome, de explorá-la, encenando-a ou autorizando-a que o façam; de reproduzi-la". 
Julgou, por essa forma, procedente a ação, condenando a ré a pagar à autora a quantia de $\mathrm{Cr} \$ 7.200,00$, juros de mora, que se consideram implícitos no pedido, contados da citação, custas e honorários advocatícios, arbitrados a $15 \%$ sobre o valor da causa, ex vi do disposto no art. 64, do C.P.C., redação da Lei $n^{\cdot} \cdot 4.632 / 65$.

\section{Duração do contrato. Suspensão e resolução}

Não contém a nossa lei dispositivo correspondente ao da lei francesa de 11-03-1957:

Art. 44. O contrato de representação é concluído por uma duração limitada ou por um número determinado de comunicações ao público.

Salvo estipulação expressa de direitos exclusivos, ele não confere ao empresário de espetáculos monopólio algum de aproveitamento.

A validade dos direitos exclusivos concedidos por um autor dramático não pode exceder cinco anos; a interrupção das representações no decurso de dois anos consecutivos lhe põe fim de pleno direito.

Depois de lembrar que não se apresenta, portanto, problema algum quando chegar o prazo estabelecido, e que, se houver recondução do contrato, este não poderá ser, novamente, senão por uma duração limitada ou por um número determinado de comunicações ao público, separa ROBERT PLAISANT as hipóteses de força maior ou caso fortuito da suspensão ou ruptura relacionadas ao fato de um dos contratantes.

Como exemplos colhidos da jurisprudência de casos em que o empresário de espetáculos pode ser exonerado de sua obrigação se o aproveitamento tornou-se impossivel, apresenta a da doença ou morte do artista contratado. maior:

De julgados não reconhecendo nem caso fortuito, nem de força

- a recusa pelo artista, do compromisso que lhe é proposto, a greve dos artistas ou do pessoal da empresa de espetáculos;

- a proposta de modificações de textos introduzidas pelo autor e não aceitas pelo diretor;

- o receio de um revés quando a peça tenha sido recebida a título definitivo.

Quanto à suspensão ou ruptura decorrente do fato de um dos contratantes, lembra que o exercício do direito moral por parte do autor, principalmente, o de arrependimento e de retirada, pode acarretar 
a suspensão ou a ruptura do contrato e sob certas condições obrigar o autor a indenizar o cessionário.

Mas também a modificação da situação jurídica do empresário de espetáculos ocasiona eventualmente a suspensão ou a resolução do contrato concluído a título pessoal.

Para demonstrar que a ruptura do contrato de representação decorrente de fato de um dos contratantes é relativamente freqüente, cita acórdão de 19-06-1963 do Tribunal do Sena, relativo à concessão a representação de uma peça dramática num teatro de Paris, que devia ter início nas proximidades de 20-05-1958.

Os acontecimentos públicos que se produziram nessa ocasião podia justificar numa certa medida algumas hesitações do diretor do teatro; ele protestou todavia, em seguida, dificuldades de decoração, e ainda a mobilização de um jovem comediante.

Decorridos alguns meses, tendo passado o periodo das férias, a peça poderia ter sido representada no mês de outubro, mas o tempo passou sem que o contrato tivesse sido executado. $O$ diretor foi então condenado por ruptura de contrato às perdas e danos de 10.554 frances, por prejuízo material e 3.000 por prejuízo moral.

\section{A representação, de lege ferenda}

Se embargo do obsoletismo dos dispositivos do $\mathrm{CC}$, com poucas alterações, foram aproveitados no Projeto de Código de Obrigações de 1965, que se limitou a introduzir três inovações.

A do art. 703, outorgando ao empresário a faculdade de promover outras representações pelo tempo e nos lugares convencionados, e, em falta de ajuste, segundo os usos e as circunstâncias; a do art. 706 não permitindo ao produtor ou empresário, sem licença do autor, fazer alterações no texto original, e a do art. 707, esta sim digna de encômios:

O autor da obra artística ou literária tem direito a ser remunerado pela sua representação ou difusão por qualquer meio, ainda que promovida sem finalidade lucrativa.

Parágrafo único. Igual direito é reconhecido aos artistas que, por exibição ao vivo, gravação ou qualquer processo mecânico, realizam a difusão da obra alheia.

Não lhe aproveitou as sugestões o Anteprojeto de CC de 1973, muito mais apegado ao texto de Código. Aditou o duvidoso parágrafo único do art. 770, que complementando o art. 1.360 (que reconhece ao autor, quando não tenha sido fixado prazo à representação, o direito de intimar o empresário para tal fim, cominando-lhe em pena a rescisão do contrato), propõe não poder "o autor assinar prazo que contravenha às normas usuais na espécie, ou prive o contrato dos resultados esperados pelo empresário" 
Teve porém o Projeto de 1975 o bom senso de retirar os dispositivos referentes à representação dramática, deixando assim a regulamentação da matéria à legislação específica, que, no entanto, terá fatalmente que ser revista e atualizada.

\section{Bibliografia aproveitada}

BILE, Franco - Rappresentazione e Esecuzione (Contratto di) Novissimo Digesto Italiano, Turim, Utet, vol. XIV, 1967, págss. 875-879.

BOBBIo, Pedro Vicente - Direito Autoral de Execução, Representação e Irradiação, São Paulo, Sbacem, 1947, págs. 5-13.

CHAves, Antônio - Tratado de Direito Civil, Contratos, São Paulo, Ed. Rev. dos Tribunais, 1984, no 40 .

CHAVES, Antônio - Direito Autoral de Radiodifusão, São Paulo, Ed. Rev. dos Tribunais, 1952, págs. 126-226.

DESBOIS, Henri - Le Droit d'Auteur en France, Paris, Dalloz, 2 ed., 1966, págs. 293-334.

DUVAL, Hermano - Direitos Autorais nas Invenções Modernas, Rio, Andes, 1956 , págs. 215-270.

FERNANDES, Milton - Contratos de representação e de execução públicas de obras intelectuais, Revista Internacional do Direito Intelectual, RIDI, 1(2), 1978, págs. 140-149.

LE TARNEC, Alain - Manuel de la Propriété Littéraire et Artistique, Paris, Dalloz, 1966, págs. 90-102.

PIZARRO DAVILA, Edmundo - Los Bienes y Derechos Intelectuales, Lima, Arica, 1974, págs. 315-326.

PLAISANT, Robert - Le Droit Pécuniaire. Le droit de représentation, Juris Classeur de la Propriété Littéraire et Artistique, Paris, Ed. Téchniques, fasc. 14, 1965, 20 págs.

PLAISANT, Robert - Radiodifusion et Télévision in Juris Classeur de la Propriété Littéraire et Artistique, Paris, Editions Téchniques, fasc. 16, 1963, 15 págs.

POUILLET, Eugène - Traité Théorique et Pratique de la Propriété Littéraire et du Droit de Répresentation, Paris, Librairie Générale, 1908.

RUDAKOV, Yu. S.j- Protection du droit d'auteur afférent aux oeuvres littéraires interprétées sans pusique dans des concerts, cirques et programmes analogues, relatório apresentado aos 11-05-1982, no Congresso de Viena da Comissão Jurídica e de Legislação da Confederação Internacional das Associações de Autores e Compositores.

STRASCHNOV, Georges - Le Droit d'Auteir et les Droits Conexes en Radiodiffusion, Bruxelas, Bruylant, 1950, págs. 19 e seguintes. 